\title{
Effect of carbohydrate supplementation on plasma glutamine during prolonged exercise and recovery.
}

Citation for published version (APA):

van Hall, G., Saris, W. H. M., \& Wagenmakers, A. J. M. (1998). Effect of carbohydrate supplementation on plasma glutamine during prolonged exercise and recovery. International Journal of Sports Medicine, 19(2), 82-86. https://doi.org/10.1055/s-2007-971886

Document status and date:

Published: 01/01/1998

DOI:

10.1055/s-2007-971886

Document Version:

Publisher's PDF, also known as Version of record

\section{Please check the document version of this publication:}

- A submitted manuscript is the version of the article upon submission and before peer-review. There can be important differences between the submitted version and the official published version of record.

People interested in the research are advised to contact the author for the final version of the publication, or visit the DOI to the publisher's website.

- The final author version and the galley proof are versions of the publication after peer review.

- The final published version features the final layout of the paper including the volume, issue and page numbers.

Link to publication

\footnotetext{
General rights rights.

- You may freely distribute the URL identifying the publication in the public portal. please follow below link for the End User Agreement:

www.umlib.nl/taverne-license

Take down policy

If you believe that this document breaches copyright please contact us at:

repository@maastrichtuniversity.nl

providing details and we will investigate your claim.
}

Copyright and moral rights for the publications made accessible in the public portal are retained by the authors and/or other copyright owners and it is a condition of accessing publications that users recognise and abide by the legal requirements associated with these

- Users may download and print one copy of any publication from the public portal for the purpose of private study or research.

- You may not further distribute the material or use it for any profit-making activity or commercial gain

If the publication is distributed under the terms of Article $25 \mathrm{fa}$ of the Dutch Copyright Act, indicated by the "Taverne" license above, 


\title{
Effect of Carbohydrate Supplementation on Plasma Glutamine During Prolonged Exercise and Recovery
}

\author{
G. van Hall, W. H. M. Saris, A. J. M. Wagenmakers
}

Department of Human Biology University of Maastricht, Maastricht, The Netherlands

G. van Hall, W. H. H. Saris, A.J. M. Wagenmakers, Effect of Carbohydrate Supplementation on Plasma Glutamine During Prolonged Exercise and Recovery, Int. J. Sports Med., Vol. 19, pp. 82-86, 1998.

Accepted after revision: August 8, 1997

Muscle glycogen and glucose have been suggested to be carbon-chain precursors for glutamine synthesis in skeletal muscle. Therefore, the aim of the present study is to investigate whether carbohydrate supplementation affects plasma glutamine and other amino acids during exercise and $7 \mathrm{~h}$ of recovery. Eight well-trained subjects cycled at an alternating workload of 50 and $80 \% W_{\max }$ until exhaustion (59 to $140 \mathrm{~min}$ ). During the exercise bout the subjects received either water (control) or a carbohydrate (CHO) drink $\left(83 \mathrm{~g} \mathrm{CHO} \cdot 1^{-1}, 2 \mathrm{ml}\right.$. $\mathrm{kg}^{-7}$ per $\mathrm{kg}$ body weight every $15 \mathrm{~min}$ ). Plasma glutamine concentration appeared not to be affected by exercise, as a significant increase was only observed at some points in time during the control test. During recovery, however, plasma glutamine concentration decreased from $682 \pm 24$ and $685 \pm 19 \mu \mathrm{mol} \cdot \mathrm{I}^{-1}$ at exhaustion to $552 \pm 19$ and $534 \pm 12 \mu \mathrm{mol} \cdot \mathrm{I}^{-3}$ after $2 \mathrm{~h}$ of recovery for the control and $\mathrm{CHO}$ test, respectively. Plasma glutamine concentration returned to pre-exercise values after $7 \mathrm{~h} \mathrm{of}$ recovery. Alanine concentration increased during exercise in both tests. During the recovery period the concentration of alanine $(48 \%)$, and total amino acids $(23 \%)$ decreased below the pre-exercise level. The plasma alanine and the total amino acid concentration was still suppressed after $7 \mathrm{~h}$ of recovery. In conclusion, carbohydrate supplementation had neither an effect during exercise nor during recovery on the concentration of plasma glutamine or other amino acids. Exercise, however, causes a substantial decrease in the plasma amino acid concentration during recovery.

Key words: Ammonia, amino acids.

Int. J. Sports Med. 19 (1998) 82-86

(1) Georg Thieme Verlag Stuttgart. New York

\section{Introduction}

Glutamine is the most abundant amino acid in human plasma and muscle. In muscle glutamine accounts for $60 \%$ of the total intracellular muscle free amino acid pool (excluding the nonprotein amino acid taurine) (2). In the postabsorptive state glutamine (48\%) and alanine (32\%) together account for $80 \%$ of the amino acids released from skeletal muscle (19), implying that glutamine with two $\mathrm{N}$-atoms per molecule is dominant for the amino acid $\mathrm{N}$-release from muscle. In the $\mathbf{4}$ hour period after the ingestion of a mixed meal the dominance of glutamine in carrying $\mathrm{N}$ out of skeletal muscle is even greater. Glutamine then accounts for $71 \%$ of the amino acid release and $82 \%$ of the $\mathrm{N}$ release from muscle (9). As the relative occurrence of glutamine in muscle protein is only $10-15 \%$ this indicates that the glutamine de novo synthesis in muscle is substantial 24 hours per day. Tracer studies in man $(7,22)$ also indicate that production rates of glutamine are higher than of any other amino acid and that glutamine is more important than alanine as a vehicle for transporting amino acid carbon and nitrogen from muscle through the plasma to the sites of oxidation. Recent tracer studies also suggest that glutamine is more important than alanine as a gluconeogenic precursor in postabsorptive humans (22).

The biochemical pathways in muscle that contribute to glutamine production in skeletal muscle are only partly known. In the postabsorptive state the uptake of glutamate from the circulation accounts for $18-65 \%$ of the glutamine production (mean value of 5 studies is $40 \%)(9,10,19,22,29)$. Part of the glutamine production in the postabsorptive state also results from the net breakdown of muscle protein (22). Protein degradation not only produces glutamine directly, but also leads to the production of branched-chain amino acids, glutamate, aspartate and asparagine. The carbon skeletons of these amino acids have all been shown to be used for de novo synthesis of glutamine in incubated rat muscles $(4,30)$. Sir Hans Krebs (16) suggested that the carbon skeletons of muscle glycogen and blood glucose are also used for synthesis of TCA cycle intermediates and glutamine. The reaction used for conversion of glycolytic 3-carbon molecules to TCA cycle intermediates either is reversal of the phosphoenolcarboxykinase reaction (16) or pyruvate carboxylase (8). Exercise leads to an increase in glutamine release from muscle $(10,27,29)$. However, this increase was only temporary during 90 min of one leg exercise at $60-65 \% \mathrm{~W}_{\max }(29)$. A decrease in plasma glutamine was ob- 
served during and following 4 hours of treadmill running at $40 \% \mathrm{VO}_{2}$ max leading to glycogen depletion in untrained subjects (25). Such decreases in plasma glutamine may be important as it has been suggested to be associated with immune system impairment in overtrained athletes (24). Here we investigated whether decreases in plasma glutamine and other amino acids were also observed during and following prolonged high intensity exercise with elite cyclists and whether glucose ingestion could prevent such decreases in line with the suggestion that glucose is a carbon-chain precursor for glutamine synthesis.

\section{Material and Methods}

\section{Subjects}

Eight healthy and highly trained male cyclists, competing at national and international level participated in the study ( 4 professional cyclists and 4 amateur cyclists from the Dutch national team). The subjects were informed about procedures and possible risks involved before giving their voluntary consent to participate. Their age, weight, and length (mean \pm SD) were $20.9 \pm 2.4 \mathrm{yr}, 73.3 \pm 4.6 \mathrm{~kg}$, and $1.82 \pm 0.04 \mathrm{~m}$, respectively.

\section{Protocol}

The subjects were studied while exercising on an electromagnetically braked cycle ergometer (Lode, The Netherlands) at a freely chosen, power output independent pedalling rate (60120 revolutions $\cdot \mathrm{min}^{-1}$ ). Before the experiment (on a separate day) each subject performed a maximal workload test to determine their maximal work output $\left(W_{\max }, 407 \mathrm{~W} \pm 20\right)$ as described previously (17). The subjects were studied during exercise until exhaustion and 7 hours of recovery on two separate occasions, first the control test when only water was ingested followed by the carbohydrate supplementation test. The study was not randomized since carbohydrate supplementation is expected to improve performance and thus subjects would have exercised longer thereby partly abolishing the effects of carbohydrate supplementation during the recovery phase. Therefore, time to exhaustion was determined in the control trail and repeated in the carbohydrate trail. Although we cannot exclude an order effect these effects are expected to be minimal as the subjects were all familiar with cycle ergometer exercise at these intensities in the laboratory. The athletes are used to performing this kind of intense exercise daily and, therefore, at least three days of recovery between the test appears to be more than sufficient for recovery. Therefore, an order effect due to training or insufficient recovery appears to be small. Both tests were peformed within 2 weeks of assessment of $W_{\text {max }}$. During the test days the subjects reported to the laboratory at $7.30 \mathrm{a} . \mathrm{m}$. after an overnight fast. They were allowed to eat a standardized breakfast that consisted of two sandwiches with marmalade and water or tea. The exercise bout started at 8.45 with a warming-up period of 5 min at $100 \mathrm{~W}$ followed by 5 min at $50 \% \mathrm{~W}_{\text {max }}$. The subjects then cycled at alternating exercise intensities in blocks of $6 \mathrm{~min}$ at $80 \% \mathrm{~W}_{\max }$ and $3 \mathrm{~min}$ at $50 \% \mathrm{~W}_{\max }$ until exhaustion was reached. Exhaustion was defined as the inability to maintain a pedalling rate above the 60 revolutions $\cdot \mathrm{min}^{-1}$ despite encouragement. During the control test the subjects had to drink $4 \mathrm{ml} \cdot \mathrm{kg}^{-1}$ body weight water in the warming-up period and then every $15 \mathrm{~min} 2 \mathrm{ml} \cdot \mathrm{kg}^{-1}$ body weight of water. After the exercise bout they were only allowed to drink water or tea without sugar. The test with carbohydrate ingestion was performed at least 3 days after the control test. The standardized breakfast at 7.30 a.m. was supplemented with 0.5 liter of a carbohydrate drink ( $166 \mathrm{~g} \mathrm{CHO} \cdot 1^{-1}$, Perform, Wander Ltd., Bern, Switzerland) replacing water or tea. The exercise bout started at 8.45 and was performed as described for the control test. During the warming-up period the subjects had to drink $4 \mathrm{ml} \cdot \mathrm{kg}^{-1}$ body weight of the carbohydrate drink $\left(83 \mathrm{~g} \mathrm{CHO} \cdot \mathrm{I}^{-1}\right)$ and then every $15 \mathrm{~min} 2 \mathrm{ml} \cdot \mathrm{kg}^{-1}$ body weight of the same CHO-drink, water was provided ad libitum during the whole test. Exercise was terminated for each subject at the exact moment that exhaustion was reached in the control test. During the recovery phase they were only allowed to drink water or tea without sugar.

\section{Analysis}

Blood was sampled during the exercise bout and 7 hour recovery from a forearm vein using a catheter kept patent by flushing with saline. Samples were obtained just before warmingup and at the end of the $80 \% W_{\max }$ blocks at $34,61,88$, $124 \mathrm{~min}$, and at the moment of exhaustion. During the recovery period blood samples were obtained after 20, 40, 60, 120 , 180,300 and 420 min of recovery. Heparinized blood was centrifuged immediately to obtain plasma; aliquots of plasma were frozen for analysis of glucose, lactate, and ammonia. Plasma for the analysis of amino acids was deproteinized with sulfosalicyclic acid ( $6 \mathrm{mg} \cdot 100 \mu \mathrm{l}^{-1}$ plasma) and analyzed by HPLC (Pharmacia, The Netherlands) (28) and stored at $-80^{\circ} \mathrm{C}$. Ammonia was measured using a modification of the enzymatic determination with glutamate dehydrogenase (14) performed on a COBAS BIO analyzer (Roche, The Netherlands), Plasma lactate and glucose were analyzed with standard enzymatic techniques on a COBAS BIO analyzer.

\section{Statistics}

All date are means $\pm S E M$. Significant differences were determined between related samples of the same subject in the two tests and differences of the same subject at different times during exercise and recovery with one-way repeated measures analysis of variance (ANOVA), location of significance was determined with the Fisher protected least significance difference test. Statistical significance was set at $P<0.05$.

\section{Results}

\section{Performance}

Exercise time to exhaustion with the alternating workload protocol of 6 min at $80 \% \mathrm{~W}_{\max }$ and $3 \mathrm{~min}$ at $50 \% \mathrm{~W}_{\max }$ varied from 59 to 140 min. Plasma lactate concentrations were higher in the subjects with the relatively short exercise times. Seven of the eight subjects were able to continue exercise with carbohydrate ingestion for the same period of time as they had reached in the control test.

\section{Plasma metabolites}

Plasma glucose concentration during the exercise bout was similar for both tests. During the recovery period, however, plasma glucose concentration increased the first $40 \mathrm{~min}$ in the test with carbohydrate ingestion whereas the plasma glu- 
cose concentration decreased to pre-exercise concentrations in the control test (Fig.1). No significant differences were observed between the test with carbohydrate supplementation and control test for plasma ammonia and lactate concentration during exercise and recovery (Fig. 1). Plasma ammonia gradually increased with exercise duration. Plasma lactate increased fourfold compared to resting level during the first 30 min of exercise but then remained constant until exhaustion (Fig. 1). During the first hour of recovery a sharp fall was observed in plasma ammonia and lactate concentration and within $40 \mathrm{~min}$ of recovery their concentrations returned to pre-exercise values. Plasma glutamine concentration increased significantly during exercise in the control test and alanine increased in both tests (Fig. 2). The concentration of plasma glutamine and alanine declined rapidly during the initial phase of recovery and reached the lowest concentration after 2 hours. Both glutamine and alanine concentrations decreased below pre-exercise concentrations but glutamine returned to pre-exercise concentrations after 5 to 7 hours of recovery whereas alanine remained low even after 7 hours of recovery (Fig. 2). Plasma glutamate increased during the first 20 to 40 min of recover. The pre-exercise BCAA concentration in the control test was significantly higher than in the carbohydrate supplementation test. The BCAA decreased with exercise and during the first hour of recovery. Plasma BCAA concentration in the control test remained below the pre-exercise con-
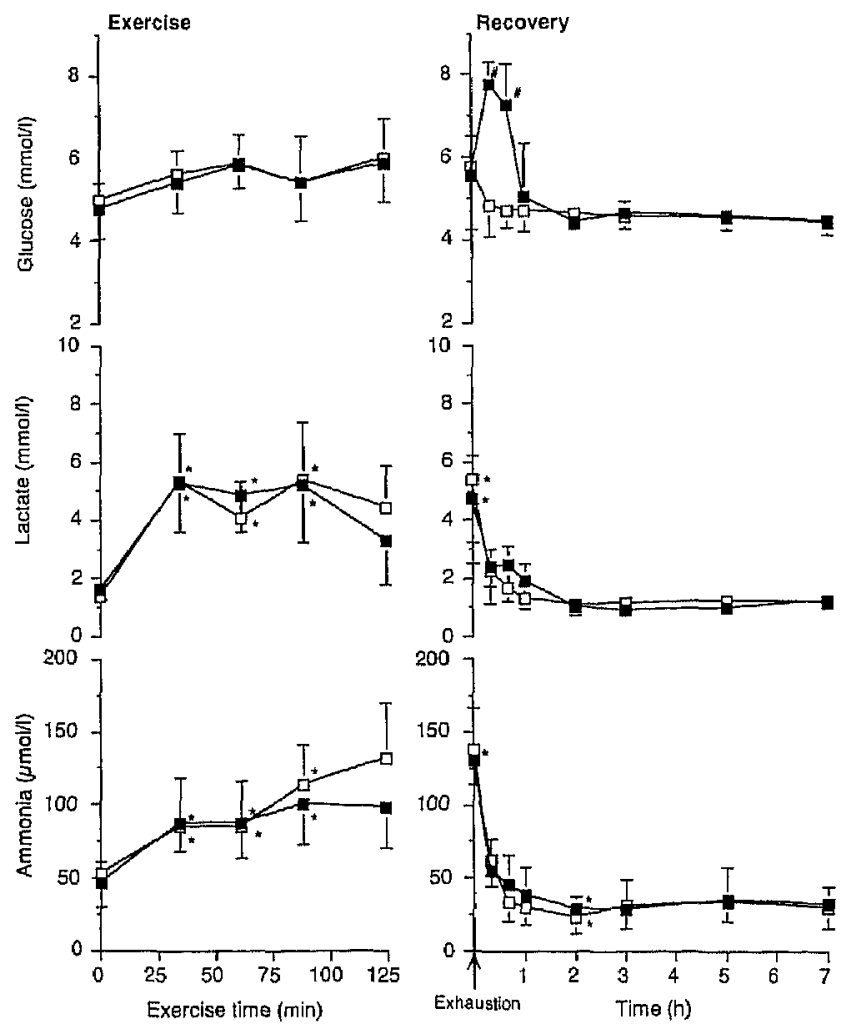

Fig. 1 Plasma glucose, lactate and ammonia in 8 highly trained subjects during exercise and recovery. Values are means \pm SEM obtained in the carbohydrate supplementation test (closed squares) and the control test (open squares). Values during exercise are of 8 subjects at $34 \mathrm{~min}$, of 7 subjects at $61 \mathrm{~min}$, of 5 subjects at $88 \mathrm{~min}$ and of 2 subjects at $124 \mathrm{~min}$. ${ }^{*}$ Significant differences from the pre-exercise concentration during exercise a well as recovery, " significant differences between the carbohydrate- and control test. centration but in the carbohydrate supplementation test plasma BCAA concentration returned to pre-exercise concentration within 5 hours. The absolute BCAA concentration during recover was equal for both tests (Fig. 2 ). The pattern of total plasma amino acid concentration resembles that of alanine and glutamine since these amino acids together account for about $40-50 \%$ of the total amino acid concentration.

\section{Discussion}

The new finding in this study is that the concentration of most plasma amino acids shows a remarkable (10-25\%) decrease after moderate to high intensity exercise performed in blocks alternating at $80 \%$ and $50 \% \mathrm{~W}_{\max }$ simulating intense cycling competition of relatively short duration (1-2 hours). The

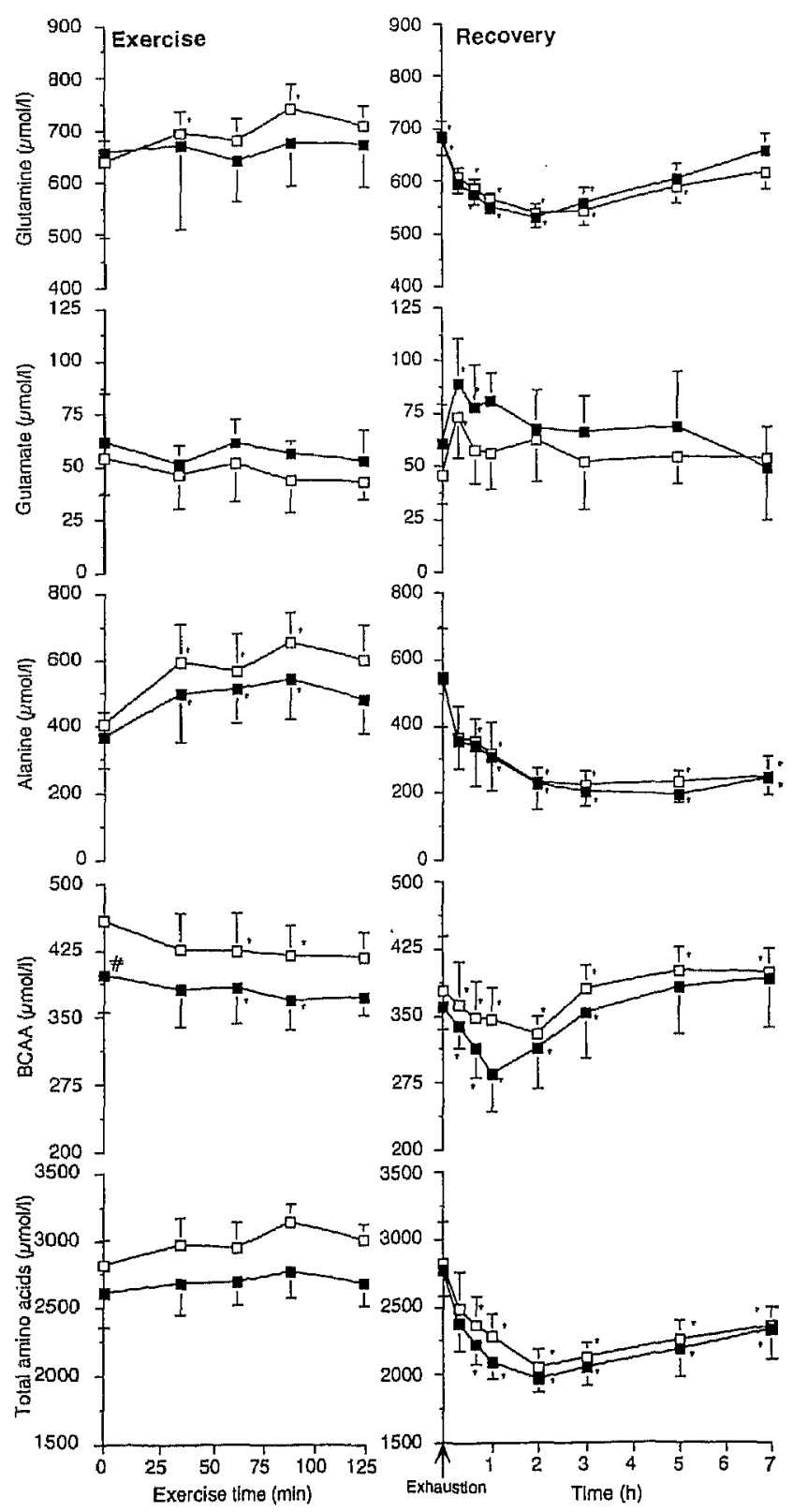

Fig. 2 Plasma amino acid concentration during exercise and recovery. Details are given in legend to Fig. 1. 
mechanism behind the post-exercise decrease in the plasma amino acid concentration is not clear. One possibility is a temporary increase of muscle protein synthesis rates and net muscle protein deposition as has been observed during recovery from 4 hours of cycling exercise at $40 \% \mathrm{VO}_{2} \max$ (5) during recovery from resistance exercise (6). It also cannot be excluded that an increased clearance of plasma amino acids by other tissues (e.g. gut, liver) contributes to the reduction of plasma amino acid concentration.

The post-exercise reduction of the plasma concentration is also seen for alanine and glutamine. These amino acids are special as they are rapidly synthesized de novo in human skeletal muscle at rest from branched-chain amino acids (BCAA) and carbon-chain precursors as pyruvate and $\alpha$-ketoglutarate both after consumption of a protein containing meal and in the postabsorptive state $(11,12,22)$. In the BCAA aminotransferase reaction the amino group is donated to $\alpha$-ketoglutarate (BCAA $+\alpha$-ketoglutarate $\leftrightarrow \mathrm{BC} \alpha$-keto acids + glutamate). In the reaction catalyzed by glutamine synthase, glutamate may then react with ammonia to give glutamine the main non-toxic amino group carrier released by human skeletal muscle 24 hours a day. Alternatively, glutamate may donate the amino group to pyruvate to form alanine, a reaction catalyzed by alanine aminotransferase (glutamate + pyruvate $\leftrightarrow$ alanine $+\alpha$ ketoglutarate). In the postabsorptive state muscle glutamate uptake from the circulation can account for $40 \%$ of the muscle glutamine production (mean value of $9,10,19,22,29$ ). Exercise leads to significant change in the rate at which alanine and glutamine are released by skeletal muscle $(1,10,11,15,29)$. Felig (11) was the first to report that the alanine output increased greatly with and in proportion to the exercise intensity and the rate of glycolysis and pyruvate accumulation. During prolonged exercise at moderate work load the release of both alanine and glutamine increased during the first $30 \mathrm{~min}$ and then gradually returned to resting values when exercise was continued for $90 \mathrm{~min}(29)$. This may indicate that the rate of alanine and glutamine production is reduced when the glycogen concentration in muscle is decreased towards exhaustion of prolonged exercise and maybe also following exercise.

The other major finding of this study is that oral ingestion of carbohydrates prior to and during exercise has no effect on the concentration of plasma glutamine, alanine and ammonia during exercise and cannot prevent the post-exercise decrease in plasma glutamine and other amino acids. This may imply that blood glucose is relatively unimportant as a precursor for muscle glutamine production during and following prolonged intense exercise in contrast to the original suggestion of Sir Hans Krebs (16).

After prolonged intense exercise the number of lymphocyte in the blood is reduced, and the function of natural killer cells is suppressed; furthermore, secretory immunity is impaired (23). During this time of immuno-suppression, referred to as "open window" phenomenon, the host may be more susceptible to microorganism by passing the first line of defense (23). Glutamine has more metabolic functions than any other amino acid and is considered as a conditionally essential amino acid in catabolic stress situation (18). Among other functions, glutamine is consumed by rapidly dividing cells such as cells of the immune system probably for both energy and as a metabolic precursor for cell replication (18). Newsholme and col- leagues have linked decreases in plasma glutamine to a weakened immune reponse in heavily training and overtrained athletes $(20,21,24)$, although experimental evidence for the existence of such a link is lacking. However, the clear parallelism between the time course of the reduction in glutamine concentration after intense exercise observed in this study and the "open window" phenomenon is remarkable. Recently, Rhode et al. (26) found in a time course of several days after a marathon race that serum glutamine concentration was correlated with changes in lymphokine activated killer cell activity but not with natural killer cell activity or proliferation (26). The practical message of this study is that similar decreases in plasma glutamine as observed in overtrained athletes also are seen in the 7 hour period following prolonged intense exercise in elite athletes on a training schedule. Further research is needed to investigate whether this decrease is related to the "open window" phenomenon and whether nutritional means can be used to prevent the decrease in plasma glutamine and the "open window" phenomenon in parallel. This study finally shows that carbohydrate ingestion during exercise does not prevent the post-exercise decrease in plasma glutamine and the "open window" phenomenon in parallel. This study finally shows that carbohydrate ingestion during exercise does not prevent the post-exercise decrease in plasma glutamine.

\section{References}

1. Ahlborg G, Felig P, Hagenfeld L, Hendler R, Wahren J. Substrate turnover during prolonged exercise in man. J Clin Invest 1974; 53: $1080-90$

2. Bergström, J, Fürst $P$, Hultman E. Free amino acids in muscle tissue and plasma during exercise in man. Clin Physiol 1985; 5: $155-60$

3. Broberg S, Sahlin K. Adenine nucleotide degradation in human skeletal muscle during prolonged exercise. J Appl Physiol 1989; 67: $116-22$

4. Chang TW, Coldberg AL. The metabolic fates of amino acids and the formation of glutamine in skeletal muscle. J Biol Chem 1978; 253: 3685-95

5. Carraro F, Stuart CA, Hartl WH, Rosenblatt J, Wolfe RR. Effect of exercise and recovery on muscle protein synthesis in human subjects. Am J Physiol 1990; 259: E470-E476

6. Chesley A, McDougall JD, Tarnopolsky MA, Atkinson SA, Smith $\mathrm{K}$. Changes in human muscle protein synthesis after resistance exercise. J Appl Physiol 1992; 73: 1383-8

7. Darmaun D, Matthews D, Bier D. Glutamine and glutamate kinetics in humans. Am J Physiol 1986; 251: E117-E126

8. Davis EJ, Spydevold $\emptyset$, Bremer J. Pyruvate carboxylase and propionylCOA carboxylase as anaplerotic enzymes in skeletal muscle mitochondria. Eur J Biochem 1980; 110: 255 - 62

9. Elia M, Schlatmann A, Goren A, Austin S. Amino acid metabolism in muscle and in the whole body of man before and after ingestion of a single mixed meal. Am J Clin Nutr 1989; 49: $1203-10$

10. Eriksson LS, Broberg S, Björkman O, Wahren J. Ammonia metabolism during exercise in man. Clin Physiol 1985; 5: 325-36

11. Felig P. Amino acid metabolism in man. Ann Rev Biochem 1975; 44: $933-55$

12. Goldberg $A L$, Chang TW. Regulation and significance of amino acid metabolism in skeletal muscle. Fed Proc 1978; 37: $2301-7$

13. Golden MHN, Jahoor P. Jackson AA. Glutamine production rate and its contribution to urinary ammonia in normal man. Clin Sci $1982 ; 62: 29-305$ 
14. Janssen MA, Van Berlo C, Van Leeuwen PAM, Soeters PB. The determination of ammonia in plasma and whole blood. In: Soeters PB, Wilson JHP, Meijer AJ, Holm E, editors. Advances in Ammonia Metabolism and Hepatic Encephalopathy. Amsterdam: Excerpta Medica 1988: 587-92

15. Katz A, Broberg S, Sahlin $K$, Wahren J. Muscle ammonia and amino acid metabolism during dynamic exercise in man. Clin Phyisol 1987; 6: 365-79

16. Krebs HA. The role of chemical equilibrium in organ function. Adv Enzym Reg 1975; 15: 449-72

17. Kuipers $\mathrm{H}$, Keizer $\mathrm{H}$, Brouns $\mathrm{F}$, Saris WHM. Carbohydrate feeding and glycogen synthesis in exercise in man. Pflugers Arch 1987; 410: $652-6$

18. Lacey JM, Wilmore DW. Is glutamine a conditionally essential amino acid? Nutr Rev 1990; 48: 297-309

19. Marliss EB, Aoki TT, Pozefsky T, Most AS, Cahill GF. Muscle and splanchnic glutamine und glutamate metabolism in postabsorptive and starved man. J Clin Invest 1971; 50: 814-7

20. Newsholme EA, Newsholme P, Curi R. The role of the citric acid cycle in cells of the immune system and its importance in sepsis, trauma and burns. Biochem Soc Symp 1987; 54: 145-61

21. Newsholme EA, Parry-Billings M. Properties of glutamine release from muscle and its importance for the immune system. JPEN 1990; 14: 63-7

22. Nurjhan N, Bucci A, Perriello G, Stumvoll M, Dailey G, Bier DM, Toft I, Jenssen TG, Gerich JE. Glutamine: A major gluconeogenic precursor and vehicle for interorgan carbon transport in man. J Clin Invest 1995; 95: $272-7$

23. Pedersen BK, Ullum $H$. NK cell response to physical activity: possible mechanism of action. Med Sci Sports Exerc 1994; 26: $140-6$

24. Parry-Billings $M$, Budgett $R$, Koutedakis $Y$, Blomstrand $E$, Brooks S, Williams C, Calder PC, Pilling S, Baigrie R, Newsholme EA. Plasma amino acid concentrations in the overtraining syndrome: possible effect on the immune system. Med Sci Sports Exerc 1992; 24: 1353-8

25. Rennie M], Edwards RHT, Krywawych S, Davies CTM, Halliday D, Waterlow JC, Millward DJ. Effect of exercise on protein turnover in man. Clin Sci 1981; 61: 627-39

26. Rohde T, MacLean DA, Hartkopp A, Pedersen BK. The immune system and serum glutamine during a triathlon. Eur J Appl Physiol 1996: 74: $428-34$

27. Sahlin KA, Katz A, Broberg S. Tricarboxylic acid cycle intermediates in human muscle during prolonged exercise. Am J Physiol 1990; 259: C834-C841

28. Van Eijck HMH, Van der Heijden MAH, Van Berlo $\mathrm{CMH}$, Soeters PB. Fully automated liquid chromatographic determination of amino acids. Clin Chem 1988; 34: 2510-13

29. Van Hall G, Saltin B, Van der Vusse GJ, Söderlund K, Wagenmakers AJM. Deamination of amino acids as a source for ammonia production during prolonged exercise. J Physiol 1995; 489: $251-61$

30. Wagenmakers AJM, Salden HJM, Veerkamp JH. The metabolic fate of branched-chain amino acids and 2-oxo acids in rat muscle homogenates and diaphragms. IntJ Biochem 1985; 17: 957 62

\section{Corresponding Author}

\section{G. van Hall}

Copenhagen Muscle Research Centre

Rigshospitalet section 7652

20 Tagensvej

2200 Copenhagen

Denmark 